\title{
KONSEP KOSMOLOGI CANDI GEDONG II DI MUARA JAMBI SEBAGAI SUMBER PEMBELAJARAN SEJARAH DI SMK NEGERI 1 PEMULUTAN SELATAN
}

\author{
Oleh: Marita Anggraini* \\ *Mahasiswa Program Studi Pendidikan Sejarah FKIP Universitas PGRI Palembang
}

\begin{abstract}
ABSTRAK
Tata letak candi Gedong II menunjukkan hubungan fungsional antara candi induk dan candi perwara. Hubungan fungsional itu berkaitan dengan sistem pantheon sekaligus prosesi ritus keagamaan. Perumusan masalah dalam penelitian ini adalah nilai sejarah apakah pada konsep kosmologi candi Gedong II di Muara Jambi sehingga dapat dijadikan sebagai sumber pembelajaran sejarah di SMK Negeri 1 Pemulutan Selatan. Tujuan dari penelitian ini adalah untuk mengetahui konsep kosmologi candi Gedong II di Muara Jambi sebagai sumber pembelajaran sejarah. Metode dalam penelitian ini adalah metode deskriptif kualitatif. Teknik pengumpulan data melalui dokumentasi, observasi, dan wawancara. Teknik analisis data yaitu reduksi data, penyajian data dan penerikan kesimpulan. Hasil penelitian menunjukkan bahwa konsep kosmologi candi Gedong II di Muara Jambi merupakan ilmu sejarah yang mempelajari alam semesta berupa tata letak candi Gedong II di Muara Jambi yang dapat dijadikan sebagai sumber pembelajaran sejarah di SMKN 1 Pemulutan Selatan.
\end{abstract}

Kata Kunci: Konsep Kosmologi, Candi Gedong II, Sumber Pembelajaran Sejarah.

\section{A. PENDAHULUAN}

Menurut Jurnal Arkeologi (Pratiwi, 2016:6-7) konsep kosmologi dalam agama Hindu/Budha merupakan jagad raya. Dalam pendirian suatu bangunan suci atau candi dikenal adanya konsep kosmologis, baik di India maupun Indonesia terutama yang menyangkut bentuk dan susunannya. Berdasarkan konsep kosmologis ini candi dianggap sebagai replika gunung Mahameru, karenanya bentuk dan susunan bangunan candi dapat dibagi dalam tiga bagian sesuai dengan lingkungan alam semesta, yaitu: (1) Bhurloka diwujudkan dalam bentuk kaki candi yang melambangkan alam manusia; (2) Bhwarloka diwujudkan dalam bentuk tubuh candi yang melambangkan alam nenek moyang; (3) Swarloka diwujudkan dalam bentuk atap candi melambangkan alam para dewa. Hubungan antara ruang dan waktu ini langsung menuju pada persoalan apakah ruang dan waktu sungguh-sungguh merupakan suatu hal yang terdapat dalam alam semesta benda-benda dan peristiwaperistiwa didalamnya.

Situs Muara Jambi telah dikenal sejak tahun 1820, ketika seseorang perwira Inggris bernama Crooke berkunjung ke daerah-daerah pedalaman Jambi untuk melakukan pemetaan perairan Sungai Batanghari dan keadaan sosial di sepanjang kawasan Sungai Batanghari dan keadaan sosial di sepanjang kawasan Sungai Batanghari. Saat mengunjungi Muara Jambi, Crooke mencatat adanya peninggalanpeninggalan purbakala. Diantara reruntuhan di desa ini terdapat satu kepala arca dari batu berambut keriting. Selanjutnya tahun 1921, situs Muara Jambi dikunjungi peneliti bangsa Belanda T. Adam yang melakukan dokumentasi foto peninggalan sejarah dan purbakala asal Jambi. Pada tahun 1935 F.M Schitger mengunjungi situs Muara Jambi dan menemukan dua arca Budha dalam posisi berdiri, satu arca nandi dan satu arca gajah bermahkota yang sekarang disimpan di Museum Sultan Mahmud Badaruddin II, Palembang (Sondang, 2009:47). 
Penelitian ini dilaksanakan di Desa Muara Jambi, Kecamatan Maresebo, Kabupataten Muara Jambi, Provinsi Jambi. Luas area candi $75 \mathrm{~m}$ x 67,5 m. Desa Muara Jambi secara administratif berada dalam wilayah kecamatan Marosebo kabupaten Muara Jambi. Berdasarkan arah mata angin, wilayah desa Muara Jambi secara administratif berbatasan dengan beberapa wilayah, yaitu: disebelah barat dan utara berbatasan dengan Desa Danaulamo. Sebagai penanda perbatasan adalah Candi Kedaton. Di sebelah timur berbatasan dengan Desa Kemimingkingluar dan Muaroselat, di sebelah selatan berbatasan dengan desa Kemimingkingdalam (Fahlen, 2009:8).

Candi Gedong II berada disisi barat candi Gedong I terletak pada titik koordinat 01028'32.76" LS dan 103039'27" BT. Kompleks Candi Gedong II memiliki luas $75 \times 67,5 \mathrm{~m}$ dan terdapat pagar keliling. Dengan pintu gerbang disisi timur didalam pagar keliling terdapat sebuah bangunan pendukung, tepat didepan bangunan induk terdapat struktur berbentuk pendopo dengan 4 buah lubang umpak (untuk tiang kayu) yang berada di tempat sisi bangunan. Berdasarkan hal tersebut bahwa rekontruksi bangunan bagian bawah merupakan struktur bangunan bata dan kontruksi diatasnya merupakan bangunan kayu beratap genteng sedangkan halaman candi tersusun atas lantai bata.

Kegiatan penyelamatan dan pembugaran candi-candi di Muara Jambi, telah menemukan beberapa arca dari batu alam. Beberapa temuan itu sudah rusak sehingga sulit untuk dikenal. Sebagian lagi masih baik walaupun telah rusak atau patah. Diantaranya yang masih banyak keutuhannnya adalah sebuah arca dewa dan dua buah arca gajah. Namun dua arca gajah tersebut ditunggangi singa yang ditemukan pada kompleks Candi Gedong II (Nazir, 1981:27).

Tujuan dari penulisan ini adalah untuk mengetahui mengenai konsep kosmologi
Candi Gedong II. Sasaran penelitian adalah teridentifikasinya mengenai Candi Gedong II di Muara Jambi yang digambarkan dalam bentuk arsitektur candi yang merupakan replika dari jagad raya. Candi pada umumnya mempunyai pagar keliling dan diluar pagar terdapat parit yang mengelilinginya. Halaman di mana candi berdiri lebih tinggi dari permukaan tanah di sekitarnya.

Kerangka pikir dalam penulisan ini adalah teori yang terkait dengan Konsep kosmologi tata ruang lingkungan dan tata ruang bangunan candi sebagai simbol mikro kosmos dan makro kosmos.

Kajian ini menggunakan Penerapan asas mikrokosmis yang bertujuan untuk membedakan ruang sakral dan ruang profan. Sedangkan asas makrokosmos bertujuan untuk memberikan gambaran atas dunia (makrokosmos) atau jagat raya ini terdiri dari: (1). Jambudwipa, sebuah benua berbentuk cincin dan tujuh benua lain berbentuk cincin juga. Di luar samudera tadi, jagat itu ditutup oleh barisan pegunungan yang sangat besar. Ditengah-tengah jambudwipa (tengah-tengah jagat raya), berdirilah gunung meru, gunung kosmis yang diedari oleh matahari, bulan dan bintang-bintang. Di puncaknya terletak kota dewa-dewa yang dikelilingi oleh tempat tinggal dari delapan lokapala atau dewadewa penjaga jagat (Handinoto, 2015:15).

\section{B. METODE PENELITIAN}

Berdasarkan rumusan masalah, penelitian ini mendeskripsikan secara rinci tentang konsep kosmologi Candi Gedong II di Muara Jambi sehingga dapat dijadikan sebagai sumber pembelajaran sejarah di SMK Negeri 1 Pemulutan Selatan. Untuk memahami hal tersebut, dilakukan penelitian secara mendalam dengan menggunakan pendekatan deskriptif kualitatif. Sumber Data. Sumber data dalam penelitian ini adalah: Informan, Dokumen. Tempat penelitian di kompleks percandian Muara Jambi dan di SMK Negeri 1 Pemulutan 
Selatan. Teknik Pengumpulan Data: Wawancara Mendalam, Kajian Dokumen, Observasi Langsung. Teknik Cuplikan. Peneliti dalam melakukan kegiatan penelitian ini menggunakan teknik cuplikan purposive sampling. Validitas Data. Validitas data sangat penting dalam proses pemaparan hasil penelitian, pembahasan dan penarikan simpulan. Dengan adanya validitas data triangulasi yang digunakan: triangulasi data, triangulasi metode.

\section{HASIL DAN PEMBAHASAN}

Berdasarkan hasil survey pada bangunan Candi Gedong II terdiri dari, pintu gerbang yang menghadap ke Timur, dengan 2 perwara (1 di sisi selatan bangunan candi induk dan 1 di depan candi induk), 1 candi induk dengan pagar yang mengelilingi Candi Gedong II. Luas Candi Gedong II $75 \mathrm{~m} \mathrm{x}$ 67,5 m dengan titik koordinat 01028' 32.76" LS dan 103039'27" BT. Jarak antara pintu gerbang dengan pagar 19,5 m sebelah kanan tampak dari depan dan 19,5 m dari sebelah kiri tampak depan, sedangkan jarak pintu gerbang ke perwara 5,24 m, jarak perwara ke candi induk $3,5 \mathrm{~m}$ dan jarak perwara di sisi selatan ke candi induk 3,65 $\mathrm{m}$, jarak perwara ke pagar arah selatan 262,5 m. sedangkan jarak antara pagar sebelah utara ke parit sekapung $87 \mathrm{~m}$. Pada pintu gerbang candi ditemukan relief dengan ragam hias belah rotan. Sampai sejauh ini pagar mengelilingi kompleks Candi Gedong II di Muara Jambi dengan berbentuk persegi panjang (Hasil Observasi 17 Maret 2017).

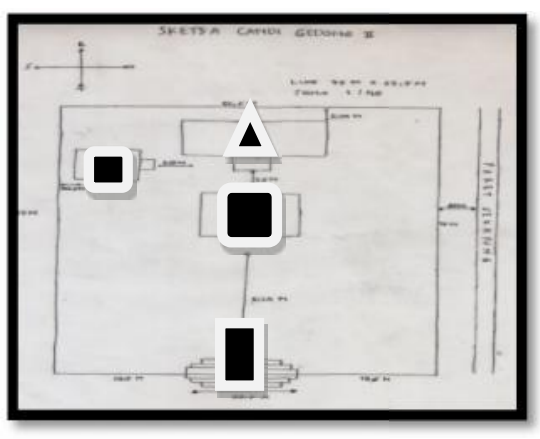

Sketsa Candi Gedong II di Muara Jambi
Keterangan:

- : Candi Induk

- : Perwara 2 (Perwara pendamping)

D : Perwara 1

(1) : Pintu Gerbang

Menurut Marhaeni (Pratiwi, 2016:57), tata letak bangunan Candi Gedong II di Muara Jambi tersusun dari bangunan induk dan bangunan-bangunan penunjang yang mengelilingi bangunan induk seperti perwara-perwara sebagai tempat persembahan. Di India, bangunanbangunan angas. Bangunan-bangunan angas dibuat untuk memenuhi kebutuhankebutuhan ruang dalam kegiatan upacara keagamaan, serta untuk mewujudkan simbol-simbol. Seperti bangunan antara yang terdapat di depan kuil merupakan simbol bagian hidung dewa yang berfungsi sebagai tempat prosesi arca. Keberadaan bangunan-bangunan penunjang di Candi Gedong II dapat dipahami melalui konsep dari India. Konsep demikian tampak pula dalam bangunan candi-candi lain di Indonesia.

Tata letak candi menunjukkan hubungan fungsional antara candi induk dan candi perwara. Hubungan fungsional itu berkaitan dengan sistem pantheon sekaligus prosesi ritual keagamaan. Dengan demikian dapat diduga bahwa perbedaan jumlah candi perwara dan tata letaknya menunjukkan perbedaan prosesi ritual keagamaan. Untuk prosesi ritual keagamaan tidak dapat direkontruksi berdasarkan arca tetapi berdasarkan pada lebar atau besar bangunan. $\mathrm{Hal}$ ini berdasarkan asumsi bahwa besarnya bangunan menunjukkan derajat kedewaan.

Situs percandian gedong II diindikasikan sebagai situs keagamaan, Pada pintu gerbang Candi Gedong II kompleks percandian Muara Jambi ditemukan arca batu yang berukuran tinggi 1,5 meter. Berbeda dengan arca penjaga di 
Jawa yang digambarkan berwajah garang, arca penjaga di jawa yang digambarkan berwajah garang, arca penjaga ini digambarkan berwajah ramah atau malah berwajah jenaka meskipun memakai misai. Rambutnya ditarik kebelakang untuk diikat menjadi sanggul. Digambarkan berdiri di atas lapik berdenah bujur sangkar. Tangan kananya memegang tameng, dan tangan kirinya memegang panggal gada (bagian atas gada telah hilang). Pada telinganya digambarkan memakai anting yang agak besar. Memakai dhoti (pakaian berbentuk cawat). Penggambaran arca seperti ini ditemukan dalam konteksnya dengan gapura gerbang masuk, adalah arca dwarapala (arca penjaga pintu gerbang). (Utomo, 2011:156).

Arca Dwarapala ditemukan di depan Gapura Candi Gedong II pada bulan april 2002. Penemuan arca ini saat para arkeolog sedang melakukan penelitian guna pekerjaan pembugaran reruntuhan struktur gapura Candi Gedong II. Dwarapala secara umum letaknya berada di kanan kiri gerbang menuju bangunan candi. Dalam ajaran sivaisme dan Budisme adalah penjaga, seperti seperti hanya menjaga pengaruh buruk yang ada di semsta, menjaga yang berbatasan antara sakral dan profan dan menjaga air keidupan (Hasil Observasi 17 Maret 2017).

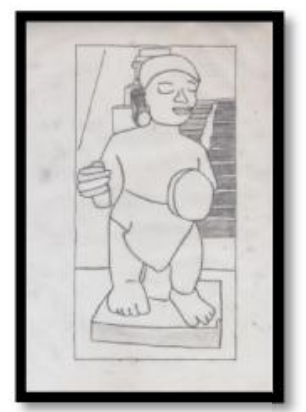

Arca Dwarapala pada Candi Gedong II

\section{Dunia Makro Candi Gedong II}

Gambaran atau citra terhadap dunia (makrokosmos), ikut menetukan tatanan mikrokosmos yang akan diwujudkan dalam penataan wilayah, ibukota, kompleks keraton, maupun bangunan pada umumnya. Seperti yang dijelaskan oleh Geldern bahwa menurut doktrin brahmana, gambaran atas dunia (makrokosmos) atau jagat ini terdiri dari: (1) Jambudwipa, sebuah benua berbentuk cincin dan tujuh benua lain berbentuk cincin juga. Di luar samudera tadi, jagat itu ditutup oleh barisan pegunungan yang sangat besar. Ditengah-tengah jambudwipa (tengah-tengah jagat raya), berdirilah gunung meru, gunung kosmis yang diedari oleh matahari, bulan dan bintang-bintang. Di puncaknya terletak kota dewa-dewa yang dikelilingi oleh tempat tinggal dari delapan lokapala atau dewadewa penjaga jagat. Menurut doktrin buddhisme gambaran atau citra atas makrokosmos ini sedikit berbeda bahwa jagat ini terdiri dari "Gunung Meru menjadi pusat dari jagat raya. Gunung ini dikelilingi ole tujuh barisan pegunungan. Masingmasing pegunungan ini dipisahkan oleh tujuh buah samudera yang berbentuk cincin. Di luar rantai pegunungan terakir terletak lautan dan di dalam lautan ini terdapat empat buah benua, masing-masing pada penjuru angin. Benua yang terletak di selatan gunung meru adalah jambudwipa, temapat tinggal umat manusia. Jagat raya pun dikelilingi oleh sebuah dinding besar yang terdiri dari batu karang, disebut barisan cakrawala. Pada lereng gunung meru terletak swarga (surga) yang terendah, yaitu swarga dari keempat raja besar atau penjaga dunia. Pada puncaknya swarga kedua, yaitu swarga ke-33 dewa serta Sudarsana, kota dewa-dewa, tempat Indra bersemayam sebagai raja. Di atas gunung meru terdapat lapisan-lapisan lainnya dari kayangan" (biasanya ada 26, termasuk lapisan-lapisan diatas gunung meru, tetapi jumlah ini kadang-kadang berbeda). Perbedaan penafsiran atas wujud jagat raya ini juga terjadi di berbagai wilayah di Asia Tenggara. Meskipun ada sedikit perbedaan dalam hal-hal kecil, wilayah-wilayah yang berpusat mengelilingi gunung meru (meru 
sebagai pusat atau center), adalah sama (Handinoto, 2015:14-15).

Pada situs Muara Jambi selain bangunan percandian juga terdapat kolamkolam kuno, danau, dan parit-parit buatan yang dihubungkan dengan sungai-sungai alam yang bermuara dijantung pelayaran Sungai Batanghari. Parit ini membentuk sebuah jaringan perairan yang cukup rumit dan membelah lokasi-lokasi dimana kompleks percandian serta sisa-sisa pemukiman kuno dibangun. Layaknya sebuah miniatur dunia, baik Sungai Batanghari, danau, kolam, dan parit merupakan satu kesatuan berlandaskan konsepsi kosmologis dalam kepercayaan Buddhisme (Widiatmokko, 2009:1).

\section{Sungai Batanghari}

Keberadaan Sungai Batanghari menjadi batas sisi selatan dataran tempat berdirinya bangunan-bangunan candi dengan dataran tepian Sungai Batanghari. Secara fisik Sungai Jambi dan Sungai Batanghari letaknya berdampingan. Namun arah alirannya cukup unik. Aliran Sungai Batanghari ke arah ilir (Timur) dan Sungai Jambi mengalir kearah hulu (Barat), meskipun pada akhirnya aliran Sungai Jambi bertemu dengan Sungai Terusan ke arah Sungai Berembang dan kembali bermuara ke Batanghari (Widiatmokko, 2009:5).

Sungai terbesar dan terpanjang di Provinsi Jambi adalah Sungai Batanghari dengan panjang $\pm 1.740 \mathrm{~km}$ dan lebar sungai diperkirakan pada kisaran 200-650 meter. Hampir semua sungai bermuara di Sungai Batanghari. Berdasarkan hasil kajian pengembangan (Master Plan) transfortasi sungai di Provinsi Jambi, tentang karakteristik Sungai Batanghari maka diperkirakan hanya kapal-kapal dengan kriteria tertentu yang dapat melalui jalur sungai ini. Seperti dengan ukuran panjang kapal diperkirakan maksimum 100 meter, dan lebar kapal maksimum 3,46 meter. Dengan mengacu pada kondisi alur rata-rata sungai di Provinsi Jambi dan dengan kriteria kapal, maka alur sungai yang dapat dilayari adalah Sungai Batanghari di daerah Sungai Batang Tebo, Sungai Batang Tembesi, serta dari Kota Jambi menuju pelabuhan Muara Sabak (Widiatmokko, 2009:1-3).

\section{Sungai Melayu}

Sungai melayu terletak disisi barat atau balakang kompleks candi gumpung, aliran sungai ini berawal di ujung sungai Jambi dan bertemu dengan sungai berembang diujung utara. Sungai melayu juga merupakan simpul bertemunya aliran parit johor disisi timur dan parit sekapung di sisi barat, yang kemudian masuk ke arah utara pada aliran sungai melayu. Disisi barat terdapat sungai medak yang aliran menghubungkan sungai melayu dengan sungai terusan.

\section{Sungai Jambi}

Sungai Jambi terletak disisi selatan dataran situs Muara Jambi mulai dari danau kelari dan berakhir disungai terusan. Keberadaan Sungai Batanghari seolah menjadi batas sisi selatan dataran tempat berdirinya bangunan-bangunan candi dengan dataran banjir tepian Sungai Batanghari. Secara fisik sungai Jambi dan Sungai Batanghari letaknya berdampingdampingan. Namun arah aliran cukup unik. Aliran Sungai Batanghari ke arah hilir (timur) dan sungai Jambi mengalir kearah hulu (barat), meskipun pada akhirnya aliran arah sungai berembang dan kembali bemuara ke Sungai Batanghari.

\section{Parit Sekapung}

Parit Sekapung letaknya sebelah Utara Kompleks Candi Gedong II. Aliran parit dimulai dari Sungai Melayu di bagian timurdan berakhir di Sungai Terusan di bagian barat. Di sepanjang Parit Sekapung sisi selatan merupakan lokasi berdirinya bangunan-bangunan candi, seperti kompleks Candi Gedong I dan Gedong II, serta reruntuhan bangunan kuno yang 
masih berwujud menapo yaitu Menapo Sekapung 1, Parit Duku, Menapo Raman, Menapo Kunyit dan Menapo Kerawe. Pada sisi utara juga terdapat gundukan tanah, namun didalamnya tidak mengandung reruntuhan bata, yaitu Menapo Sungai Melayu III, Menapo Parit Sematang Tubo, Parit Sekapung II, dan Menapo Pandir. Menapo-menapo ini hanya gundukan tanah dan dikelilingi parit sebatas luas gundukan tanah (Widiatmokko, 2009:5).

Situs Muara Jambi dalam hal ini secara simbolis fungsi parit merupakan batas antara yang sakral dan profan. Dataran yang disucikan sifatnya terikat dan dikhususkan sebagai temapat berdirinya bangunan-bangunan candi berada di dalam berdirinya bengunan-bangunan candi berada di dalam jaringan parit. Sebaliknya dataran diluar jaringan lebih bersifat longgar dan tidak secara khusus diperuntukkan sebagai lokasi bangunan candi. Demikian juga fungsi danau dan kolam-kolam kuno tidak saja secara fungsional untuk mendukung lingkungan hidup masyarakat yang berdiam dan datang di situs Muara Jambi tetapi secara simbolisme dunia makrosmos dan mikrokosmos dalam mitologi buddhisme. Dalam hal ini keberadaan kolam buatan seperti telagolajo bisa jadi mempunyai makna sebagai replika perlambang samudera dan gunungnya sendiri diwujudkan dalam gugusan bangunan candi.

\section{Dunia Mikro Candi Gedong II}

Penerapan asas mikrokosmis bertujuan untuk membedakan ruang sakral dan ruang profan. Sedangkan penerapan asas mikrokosmis dualistis bermaksud mensucikan ruang (yang tak terbatas) secara mutlak. Ruang "sakral" perlu diberi batas (dibatasi) dari ruang profan. Didalam ruang sakral (mikrokosmos) tersebut manusia bisa menata secara teratur berdasarkan kosmologi dari penghuninya. Untuk penataan lingkungan diperlukan kosmografi sebagai pedomannya. Dalam dunia mikro terdapat pusat jagat raya yang menurut pandangan masyarakat tradisional, dunia terdiri dari tiga tingkatan. Pertama adalah dunia di mana hidup, kedua dunia atas (surga) dan ketiga dunia bawah (yang sering diibaratkan sebagai dunia hitam). Pusat jagat raya (sering digambarkan secara vertikal), merupakan "pusat" dunia sebagai penghubung ketiga unsur di atas. Dalam gambaran secara fisik, pusat jagat raya ini dinyatakan seperti "pilar tunggal" (yang ada dipusat), pohon (beringin), persilangan sebagai pusat desa atau kadang-kadang juga gunung atau meru (Semeru, Merapi, Gunung Agung, dan sebagainya). Kuil atau candi juga sering diibaratkan sebagai gunung (buatan), yang dianggap sebagai "pusat" lingkaran (Handinoto, 2015:18).

Jadi pada bangunan Candi Gedong II yang menjadi pusat jagat raya yaitu candi induk karena pada bangunan candi induk dianggap sebagai kuil yang diibaratkan sebagai gunung (buatan), sebagai "pusat" lingkaran menjadi penghubung dari tiga tingkatan dunia yaitu tingkatan dunia hidup, dunia atas (surga) dan dunia bawah (dunia hitam).

Selain pusat jagat raya di dalam dunia mikro juga terdapat sumbu atau poros dapat berfungsi sebagai orientasi dan elemen penyatu serta sekaligus sebagai batas dalam mengklasifikasikan hierarki penataan ruang (berdasarkan kosmografi) di dalam ruang sakral. Mana bangunan yang harus diletakkan di sebelah kiri, mana yang sebelah kanan, demikian juga mana diatas dan mana yang dibawah, dan sebagainya. Selain itu, sumbu juga sekaligus merupakan semacam tuntutan dalam penataan susunan massa bangunan. Misalnya saja sumbu juga bisa mengatur/membagi ruang menjadi dua bagian (pemaruhan), atau empat bagian (pencaturan) dan sebagainya. Seperti yang disebutkan oleh Bertling (1923), bahwa pembagian dua (pemaruhan) lebih condong untuk masalah dunia atas dan dunia manusia (hubungan secara vertikal). 
Sedang pembagian empat (pencaturan), lebih condong dipakai untuk pembagian antar manusia di dunia (hubungan horizontal).

Sumbuh juga bisa menjadi batas/membagi mana daerah/ruang sakral dan mana daerah/ruang profan. Sumbuh atau poros biasanya selalu berpatokan pada arah mata angin, seperti utara-selatan dan timur-barat. Ditengah (perpotongan antara dua sumbuh) itulah biasanya merupakan pusat (center).

\section{Keramik}

Keramik merupakan barang pecah belah yang terbuat dari bahan batuan dan porselin, benda seperti ini banyak ditemukan di kawasan percandian Muara Jambi dalam kondisi relatif tidak utuh. Bentuk keramik yang ditemukan cukup bervariatif, diantaranya berupa guci, piring, mangkuk, botol, kendi, pasu, dan piguran binatang. Dari hasil pengamatan bahwa keramik ini pada umumnya didatangkan dari negeri Cina, dan dibuat pada periode Dinasti Tang, hingga Dinasti Ching. Namun demikian temuan keramik Dinasti Sung abad 10-13 Masehi yang paling mendominasi. Selain negeri Cina keramik ini juga berasal dari negara lain yaitu Jepang namun dalam jumlah yang sangat sedikit. Dengan ditemukan benda keramik yang berasal dari negara-negara luar menunjukkan bahwa situs di Muara Jambi pada masa itu mempunyai hubungan baik dengan negaranegara luar (Hasil Observasi, 17 Maret 2017).

\section{Pembahasan \\ Nilai Sejarah Konsep Kosmologi Candi Gedong II di Muara Jambi Sebagai Sumber Pembelajaran Sejarah di SMK Negeri 1 Pemulutan Selatan}

Nilai adalah sesuatu yang diharapkan manusia,. Nilai adalah suatu konsep yang berada dalam pikiran manusia yang sifatnya tersembunyi, tidak berada dalam dunia empiris. Nilai menjadikan manusia terdorong untuk melakukan tindakan agar harapan itu terwujud dalam harapannya.

Sejarah merupakan ilmu yang meneliti, menyelidiki peristiwa/kejadian, aktivitas manusia yang telah terjadi di masa lampau. IImu sejarah sebagai disiplin ilmu yang mempelajari dinamik dan perkembangan kehidupan manusia dan masyarakatnya yang bersifat fundamental yang memberikan pengaruh langsung mengenai sasaran pokok disiplinnya serta memberikan batasan dan sasaran yang jelas dalam usaha untuk melukiskan peristiwa masa lampau (Daliman, 2011:1).

Jadi dari penjelasan di atas dapat disimpulkan bahwa pengertian nilai sejarah adalah suatu nilai yang menyangkut segala sesuatu yang baik atau buruk dari berbagai pengalaman dengan seleksi perilaku yang ketat mengenai peristiwa-peristiwa masa lalu.

Menurut Bapak Masrullah, S.Pd. beliau sudah mengetahui nilai sejarah konsep kosmologi Candi Gedong II. Konsep kosmologi Candi Gedong II merupakan tata letak Candi Gedong II. Candi Gedong II merupakan kebudayaan Buddha yang masuk ke Indonesia ketika Kerajaan Sriwijaya berjaya, penganut Buddha banyak bermukim di daerah pedalaman. Pada masa Sriwijaya, agama dan kesenian berkembang pesat, kesenian yang berkembang khususnya seni bangunan candi, konsep kosmologi Candi Gedong II dan arca-arca yang ditujukan untuk kegiatan keagamaan (Catatan Wawancara Tanggal, 3 Mei 2017).

Menurut Ronald (2008:206), kosmologi adalah ilmu pengtahuan tentang alam ataupun dunia. Dunia dalam penyelidikan kosmologis adalah dunia sejauh yang kita alami seutuhnya. Alam semesta telah diperluas menjadi kosmologi. Selain itu, dari hasil penelitian yang dilakukan oleh peneliti maka peneliti dapat mengumpulkan data yang ada baik di sekolah maupun di lapangan mengenai konsep kosmologi Candi Gedong II di Muara Jambi. 
Berdasarkan uraian diatas konsep kosmologi dapat disimpulkan ilmu sejarah yang mempelajari alam semesta. Dengan demikian konsep kosmologi yang dimaksud disini adalah ilmu sejarah yang mempelajari alam semesta mengenai tata letak Candi Gedong II sebagai sumber pembelajaran Sejarah di SMK Negeri 1 Pemulutan Selatan.

Dalam mata pelajaran sejarah di SMK Negeri 1 Pemulutan Selatan, bahwa konsep kosmologi Candi Gedong II terdapat pada Kompetensi Dasar: 2.2 Mendeskripsikan perkembangan masyarakat, kebudayaan, dan pemerintahan pada masa HinduBuddha serta peninggalan-peninggalannya. Candi Gedong II merupakan hasil dari peninggalan-peninggalan budaya masyarakat Hindu-Buddha, hal ini dibuktikan dengan ditemukannya arca-arca yang bercorak Hindu-Buddha.

Dalam memperoleh data peneliti melakukan penelitian langsung dengan wawancara kepada guru Sejarah yaitu Bapak Masrullah, S.Pd. berdasarkan wawancara dengan Bapak Masrullah, S.Pd pada Tanggal, 3 Mei 2017. Menurut beliau bahwa penggunaan sumber pembelajaran sejarah di SMK Negeri 1 Pemulutan Selatan. Khususnya konsep kosmologi Candi Gedong II belum pernah dilakukan. Hal ini karena terbatasnya sumber-sumber bacaan yang membahas Candi Gedong II, kemudian siswa sulit untuk mendapatkan info tentang sejarah Candi Gedong II karena tata letak Candi Gedong II belum masuk dalam buku sumber sejarah yang dijadikan pedoman dalam pembelajaran sejarah.

Bapak Masrullah, S.Pd juga mengatakan bahwa materi konsep kosmologi Candi Gedong II layak untuk dijadikan sumber pembelajaran sejarah guna untuk memperkenalkan peninggalanpeninggalan budaya Hindu-Buddha, khususnya peninggalan Candi Gedong II yang ada di Kabupaten Muara Jambi kepada siswa-siswi.
Berdasarkan hasil wawancara dengan Bapak Masrullah, S.Pd (guru mata pelajaran sejarah pada tanggal, 03 Mei 2017). dengan adanya pengenalan materi konsep kosmologi Candi Gedong II sebagai sumber pembelajaran sejarah dapat menambah dan mempermudah tenaga pengajar untuk memperkenalkan peninggalan-peninggalan agama HinduBuddha konsep kosmologi Candi Gedong II yang mengenai tata letak candi diperkenalkan kepada siswa-siswi sehingga peserta didik dapat mengetahui tentang nilai sejarah konsep kosmologi Candi Gedong II.

\section{SIMPULAN}

Kawasan situs Muara Jambi berada di desa Muara Jambi, kecamatan Marosebo, kabupaten Merangin, provinsi Jambi. Berdasarkan arah mata angin, wilayah desa Muara Jambi secara administratif berbatasan dengan beberapa wilayah antara lain: di sebelah Barat dan Utara berbatasan dengan desa danau lamo. Disebelah Timur, desa Muara Jambi berbatasan dengan desa kemingkingluar dan muaroselat. Sementara di sebelah Selatan berbatasan dengan desa Kemingking Dalam. Situs Muara Jambi merupakan bangunan percandian untuk peribadatan umat Buddha yang berasal dari abad ke 9-12 Masehi. Pada bangunan situs Muara Jambi terdapat kolam-kolam kuno, danau, dan parit-parit buatan yang dihubungkan dengan anak sungai dan bermuara dijantung pelayaran Sungai Batanghari.

Konsep kosmologi Candi Gedong II di Muara Jambi mengenai tata letak Candi Gedong II. Tata letak candi menunjukkan hubungan fungsional antara candi induk dan candi perwara. Hubungan fungsional itu berkaitan dengan sistem pantheon sekaligus prosesi ritus keagamaan. Dengan demikian dapat diduga bahwa perbedaan jumlah candi perwara dan tata letaknya menunjukkan perbedaan prosesi ritus keagamaan. Dalam prosesi ritus 
keagamaan candi induk merupakan titik terakhir setelah menyelesaikan ritus di candi perwara.

\section{DAFTAR PUSTAKA}

Utomo, Budi Bambang. 2011. Kebudayaan Zaman Klasik Indonesia Batanghari. Jakarta: Dinas Kebudayaan dan Pariwisata.

Fahlen, Riri. 2009. Kehidupan Sosial Budaya Masyarakat Desa Muaro Jambi. Palembang: Balai Arkeologi Palembang.

Handinoto. 2015. Perkembangan Kota di Jawa Abad XVIII Sampai Pertengahan Abad XX. Yogyakarta: Ombak.

Sondang, M. Sireger. 2009. Arca-arca dari Muaro Jambi. Palembang: Balai Arkeologi Palembang.

Nazir, M. 1980. Arkeologi Klasik Daerah Jambi. Jambi: Proyek Pengembangan Permusiuman Jambi.

Pratiwi, Dini. 2016. Konsep Kosmologi Candi Bumiayu Sebagai Sumber Pembelajaran IPS Terpadu (Sejarah) di Kelas VII SMP Sriguna Palembang. Palembang: Universitas PGRI Palembang. (Tidak diterbitkan)

Widiatmokko. Agus. 2009. Sungai Batanghari dan Jaringan Tata Guna Air Situs Percandian Muaro Jambi. Palembang: Balai Arkeologi Palembang. 